\title{
KOMUNITAS
}

\section{DILEMA KEBERADAAN SEKTOR INFORMAL}

\section{Hartati Sulistyo Rini}

Jurusan Sosiologi dan Antropologi, Fakultas Ilmu Sosial, Universitas Negeri Semarang, Indonesia

\section{Info Artikel}

Sejarah Artikel:

Diterima Juni 2012

Disetujui Juli 2012

Dipublikasikan September 2012

Keywords:

Informal sector;

Labor;

Welfare.

\begin{abstract}
Abstrak
Sebagai sistem ekonomi alternatif, keberadaan sektor informal mengundang pro dan kontra. Peranannya yang signifikan sebagai katup pengaman ekonomi nasional belum diimbangi dengan proteksi atau perlindungan dari pemerintah. Tujuan penelitian ini adalah membahas peran sektor informal dalam mengatasi masalah sosial ekonomi masyarakat dan dilema yang dialami oleh sektor informal dalam menjalankan perannya tersebut. Hasil penelitian ini menunjukkan terdapat peran sektor informal pada bidang ketenagakerjaan dan penyerapan angka pengangguran. Sektor formal dianggap tidak mampu menyediakan kesempatan kerja untuk seluruh lapisan masyarakat, apalagi mereka yang ada pada posisi marjinal. Pada beberapa kasus-khususnya yang berhubungan dengan sektor informal perkotaan perlakuan dan kebijakan negara menjadi sangat diskriminatif karena seringkali berhadapan dengan kebijakan negara yang bahkan berakhir dengan kekerasan. Perlindungan terhadap sektor informal salah satunya adalah pada pedagang kaki lima di Surakarta. Kota ini menjadi contoh representatif dalam pengorganisasian kepentingan pemerintah dan pedagang kaki lima. Ini dapat menjadi inspirasi positif bagi penanganan sektor informal di tempat yang lain untuk memperluas lapangan kerja bagi masyarakat dan meningkatkan kesejahteraan sosial.
\end{abstract}

\begin{abstract}
As an alternative economic system, the existence of informal sector invites pros and cons. The significant role of informal sector as a safety valve of the national economy has not been matched by government with the protection or support The objective of this study is to discuss the role of the informal sector in addressing social and economic issues, and the dilemma faced by the informal sector in carrying out this role. The results of this study shows that there is an important role of the informal sector in the field of employment and unemployment absorption. The formal sector is not considered able to provide job opportunities to all levels of society, especially those in marginal positions. In some cases, particularly with regard to the urban informal sector-treatment and state policy became very discriminatory because often faced with state policies and even lead to violence. The protection of the informal sector one is on street vendors in Surakarta. The city is become representative example in organizing between the government's interest and street vendors. It can be a positive inspiration for handling informal sector in other places to expand employment opportunities for the community and increase social welfare.
\end{abstract}

(C) 2012 Universitas Negeri Semarang

Alamat korespondensi:

Gedung C7 Lantai 1 FIS UNNES

ISSN 2086-5465

Kampus Sekaran, Gunungpati, Semarang, 50229

E-mail: hsrlilis@gmail.com 


\section{PENDAHULUAN}

Bagi negara-negara berkembang keberadaan sektor informal merupakan fenomena yang tidak sulit untuk ditemukan. Hal ini bukan berarti bahwa di negaranegara maju fenomena ini tidak ada, namun keberadaan sektor informal di negara berkembang memiliki karakteristik yang "unik". Bahkan apabila ditelaah lebih lanjut, tidak jarang perkembangan sektor informal ini sering kali harus berhadapan dengan negara yang memiliki kebijakan dan kekuatan yang besar. Walaupun demikian, perkembangan sektor informal ini dapat dijumpai dari jantung ibukota negara tersebar sampai seluruh pelosok nusantara sebagai bagian dari dinamika ekonomi masyarakat.

Sektor ekonomi informal nampaknya masih mendominasi penyediaan lapangan kerja masyarakat. Laporan sosial ekonomi BPS yang dikeluarkan pada Juni 2010 mengatakan bahwa pada Februari 2010 sekitar 33,74 juta orang (31,42 persen) bekerja pada kegiatan formal dan 73,67 juta orang (68,58 persen) bekerja pada kegiatan informal. Hal ini menunjukkan bahwa sektor ekonomi informal ini memiliki kemampuan yang besar untuk menyerap potensi ketenagakerjaan Indonesia yang tidak bisa tertampung pada sektor formal.

Keluwesan sektor ekonomi informal dalam menyerap tenaga kerja ini bisa dikatakan sebagai salah satu keunggulan yang dimilikinya. Namun seiring dengan perkembangannya, keluwesan dan kemampuan sektor informal dalam memecahkan masalah ketenagakerjaan ini tidak diimbangi dengan kebijakan negara untuk mengakomodasi keberadaan mereka. Yang paling mencolok adalah apabila kita melihat keberadaan sektor informal perkotaan, pedagang kaki lima (PKL) misalnya. Cukup sering kita melihat dan mendengar bagaimana pemerintah memperlakukan sektor informal ini layaknya "anak tiri" apabila dibandingkan dengan sektor formal. Penggusuran, pemaksaan bahkan penggunaan cara-cara kekerasan dengan mudah kita temui dalam penataan dan penanganan PKL. Bila tidak mau dikatakan sebagai tren, sepertinya kecenderungan penggunaan kekerasan dalam menata PKL ini merupakan jalan yang paling mudah dan dianggap berhasil menangani masalah dalam jangka waktu yang pendek. Namun imbas di masa datang dan dalam jangka waktu panjang tidak dapat terakomodir melalui kebijakan ini.

Kemampuan sektor informal sebagai penyerap tenaga kerja yang bersifat masif namun tidak diakomodir oleh pemerintah ini, merupakan suatu kondisi dilematis dan ambivalen yang menarik untuk dikaji. Bahkan dalam beberapa peristiwa, sektor informal ini dianggap sebagai musuh yang harus diperangi. Contoh kasus di beberapa kota, baik yang dianggap berhasil mengakomodir keberadaan sektor informal maupun yang tidak berhasil, semakin mengentalkan nuansa ambivalensi dan dilematisnya posisi sektor informal perkotaan ini. Oleh karena itu, rumusan masalah yang akan dijawab dalam penelitian ini adalah: 1) bagaimana peran sektor informal dalam mengatasi masalah sosial ekonomi masyarakat; dan 2) bagaimana dilema yang dialami oleh sektor informal dalam menjalankan perannya tersebut.

\section{METODE PENELITIAN}

Penelitian ini dilaksanakan dengan metode studi kepustakaan. Menurut Zed (2008 : 4-5), terdapat 4 ciri penelitian kepustakaan, yaitu 1) peneliti berhadapan dengan teks atau data angka dan bukan dengan pengetahuan langsung dari lapangan dan saksi-saksi; 2) data pustaka bersifat siap pakai (ready made), artinya peneliti tidak pergi kemana-mana kecuali hanya berhadapan langsung dengan bahan sumber yang sudah tersedia di perpustakaan; 3) data pustaka dari sumber sekunder dalam arti bahwa peneliti memperoleh bahan dari tangan kedua dan bukan data orisinil dari tangan pertama di lapangan; 4) bahwa kondisi data pustaka tidak dibatasi oleh ruang dan waktu, karena kapanpun peneliti kembali maka data tidak akan berubah karena telah tersimpan dalam rekaman tertulis. Subyek penelitian ini adalah data berupa artikel dan 
beberapa buku sumber yang terkait dengan tema penelitian yaitu mengenai dilema keberadaan sektor informal.

\section{HASIL DAN PEMBAHASAN}

Istilah sektor informal ini mulamula diperkenalkan oleh Keith Hart yang merupakan hasil kajian mengenai aktivitas perekonomian yang unik di Accra dan Gana. Dalam penelitiannya itu dia menemukan adanya variasi yang besar dalam hal tersedianya peluang pendapatan legal dan illegal pada kelompok miskin perkotaan (Gilbert dan Gugler, 1996 : 95). Definisi sektor informal tersebut sering dilengkapi dengan suatu daftar kegiatan yang terlihat apabila seseorang menyusuri jalan-jalan suatu kota Dunia Ketiga: pedagang kaki lima, penjual koran, pengamen, pengemis, pedagang asongan, pelacur, dan lain-lain. Mereka merupakan pekerja yang tidak terikat dan tidak terampil dengan pendapatan rendah dan tidak tetap. Dari hasil penelitian Hart tentang sektor informal di dunia ketiga itulah memunculkan perhatian ilmuwanilmuwan sosial terhadap keberadaan sektor informal.

Merebaknya sektor informal ini tidak dapat kita lepaskan dari fenomena industrialisasi dan urbanisasi di perkotaan. Industrialisasi yang ditandai dengan pembangunan yang mengutamakan perkotaan (urban bias) telah mengakibatkan jurang pemisah yang bertambah lebar antara kondisi perekonomian perkotaan dan pedesaan. Dan kebanyakan negara berkembang mengabaikan sektor pertanian di desa untuk mendapatkan sumber daya dalam upaya meningkatkan usaha industrialisasi dan urbanisasi (Manning, 1995 : 11).

Masih menurut Manning (1995), kondisi urbanisasi berlebih ini menyebabkan adanya tiga gejala yang menunjukkan bahwa kota-kota telah tumbuh terlalu pesat untuk dapat mendukung pertumbuhan ekonomi di negara sedang berkembang, yaitu 1) jumlah penganggur dan setengah penganggur yang besar dan semakin meningkat; 2) proporsi tenaga kerja yang bekerja pada sektor industri perkotaan hampir tidak dapat bertambah malahan mungkin semakin berkurang; dan 3) jumlah penduduk dan tingkat pertumbuhannya sudah begitu pesat sehingga pemerintah tidak mampu memberikan pelayanan kesehatan, perumahan, dan transportasi yang memadai. Pada akhirnya permasalahan riil yang kemudian timbul adalah bukan lagi menyangkut pada pertumbuhan ekonomi semata, namun juga telah menyentuh pada masalah baru yaitu mengenai pengangguran dan segala konsekuensinya.

Selanjutnya menurut McGee dan Todaro (dalam Effendi, 1995 : 163) bahwa urbanisasi di dunia ketiga tidak diikuti oleh penambahan fasilitas perkotaan dan lapangan pekerjaan. Sehingga memunculkan kantong-kantong miskin di perkotaan dan terbentuknya nilai sosial yang mengarah ke kebudayaan kemiskinan lebih disebabkan oleh ketimpangan sosial dan ekonomi di kota ketimbang oleh proses kemiskinan di desa. Bahkan bisa jadi, proses urbanisasi ini hanya berarti memindahkan kemiskinan dari pedesaan ke perkotaan.

Pengangguran, terbatasnya lapangan pekerjaan di sektor formal, dan munculnya kantong-kantong kemiskinan tersebut pada akhirnya membuat masyarakat mencari sumber penghidupan alternatif yaitu sektor informal. Sektor informal dianggap sebagai penyelamat kehidupan, dimana mampu menyediakan pekerjaan dan penghasilan dengan kepemilikan atas modal, keahlian dan ketrampilan yang terbatas atau minim. Hal ini sesuai dengan apa yang dikemukakan oleh Hidayat (dalam Effendi, 1995 : 91) tentang karakteristik yang umum dijumpai dalam sektor informal ini, yaitu sebagai berikut : 1) kegiatan usaha tidak terorganisasi dengan baik, karena timbulnya unit usaha tidak mempergunakan fasilitas atau kelembagaan yang tersedia di sektor formal; 2) pada umumnya unit usaha tidak mempunyai izin usaha; 3) pola kegiatan usaha tidak beraturan baik dalam arti lokasi maupun jam kerja; 4) pada umumnya kebijakan pemerintah untuk membantu golongan ekonomi lemah tidak sampai ke sektor ini; 5) unit usaha mudah keluar masuk dari sub sektor ke sub sektor lain; 6) teknologi yang bersifat tradisional; 
7) modal dan perputaran usaha relatif kecil, sehingga skala operasi juga relatif kecil; 8) untuk menjalankan usaha tidak diperlukan pendidikan formal, karena pendidikan yang diperlukan diperoleh dari pengalaman sambil bekerja; 9) pada umumnya unit usaha termasuk golongan yang mengerjakan sendiri usahanya dan kalau mengerjakan, buruh berasal dari keluarga; 10) sumber dana modal usaha pada umumnya dari tabungan sendiri atau dari lembaga keuangan yang tidak resmi; dan 11) hasil produksi atau jasa terutama dikonsumsi oleh golongan kota atau desa yang berpenghasilan rendah tetapi kadang-kadang juga yang berpenghasilan menengah.

Dari beberapa kriteria yang tersebut, maka terdapat beberapa peran dari sektor informal yang mampu mendukung kondisi sosial ekonomi masyarakat. ini terkait dengan persoalan ketenagakerjaan dan keterserapan pengangguran. Tuntutan pekerjaan dengan kualifikasi pendidikan dan ketrampilan memadai di perkotaan menjadi kendala pencari kerja dalam memperoleh pekerjaan. Mereka yang pada mulanya berkeinginan bekerja di sektor formal pada akhirnya bermuara di sektor informal. Bahkan bagi mereka yang kurang beruntung pada akhirnya akan menambah panjangnya daftar pengangguran.

Menurut data Survei Angkatan Kerja Nasional (Sakernas) tahun 2007-2009 dari BPS penduduk berumur 15 tahun ke atas mengalami peningkatan yaitu 162.352 .048 orang di tahun 2007 dan 168.264.448 orang di tahun 2009. Yang patut mendapatkan perhatian adalah berkurangnya jumlah pengangguran terbuka dari angka 10.547.917 orang di tahun 2007 menjadi 9.258.964 orang di tahun 2009. Hal ini dipandang sebagai hal yang menggembirakan oleh pemerintah, karena dengan turunnya jumlah pengangguran akan berpengaruh juga pada turunnya tingkat kemiskinan masyarakat.

Masih dalam kaitannya dengan permasalahan ketenagakerjaan, penyerapan tenaga kerja di sektor informal menurut BPS pada tahun 2007 adalah $67 \%$ dari angkatan kerja yang bekerja, sedangkan di tahun 2009 angkanya mengalami kenaikan menjadi
70\%. Hal ini akan menjadi data yang menarik untuk dipelajari mengingat bahwa sektor informal mampu menyerap tenaga kerja dibandingkan dengan sektor informal. Artinya bahwa masih banyak peluang yang bisa digunakan baik oleh masyarakat atau pemerintah untuk mengembangkannya.

Namun bukan berarti masalah pengangguran akan terselesaikan begitu saja seiring dengan berjalannya waktu. Permasalahan yang muncul kemudian adalah bahwa ternyata jumlah pengangguran terdidik yang ada di Indonesia dari tahun 2007-2009 mengalami peningkatan. Berdasarkan data Sakernas, lulusan universitas yang menganggur pada tahun 2007 adalah 409.890 orang dari 10.547.917 orang, sedangkan pada tahun 2009 mengalami peningkatan yaitu 626.621 orang dari 9.258.964 orang. Sedangkan lulusan diploma yang menganggur juga mengalami kecenderungan yang sama yaitu mengalami peningkatan. Tahun 2007 lulusan diploma yang menganggur adalah 330.316 orang sedangkan di tahun 2009 jumlahnya meningkat menjadi 486.399 orang. Sedangkan pada tenaga kerja yang tidak sekolah sampai pada lulusan SMTA mengalami penurunan dari tahun ke tahun. Hal ini memperkuat indikasi bahwa semakin dalamnya kesenjangan antara banyaknya tenaga kerja dengan kesempatan kerja yang dimiliki. Oleh karena itu, kecenderungan yang terjadi sekarang adalah menimbulkan semangat kewirausahaan pada para pengangguran terdidik ini agar tidak tergantung pada keterbatasan lapangan kerja. Mereka diharapkan dapat menjadi motor dalam pembukaan lapangan kerja baru. Barangkali yang paling memungkinkan untuk dijadikan alternatif adalah sektor informal ini, karena ijazah atau kepandaian akademis bukan menjadi syarat utama melainkan kreativitas, ketrampilan dan modal.

Menurut Siswoyo (2009), semangat kewirausahaan representatif dimasukkan sebagai suplemen penting dalam pendidikan tinggi. Karena pada kenyataannya, mereka yang berpendidikan tinggi memiliki motivasi wirausaha yang rendah. Dorongan-dorongan 
berupa testimoni maupun contoh nyata bagi mereka yang berhasil di bidang wirausaha merupakan hal yang sangat penting untuk mendorong jiwa wirausaha yang mandiri, ulet, dan pantang menyerah. Selain kegiatan perkuliahan, pembekalan dan pembentukan jiwa wirausaha harus juga didukung oleh kelembagaan dan praktek-praktek nyata kegiatan dalam karya mahasiswa. Dengan demikian, sebenarnya pendidikan tinggi tidak akan tersandera dalam stigma pencetak penganggur terdidik.

Secara jelas, sektor informal telah berperan secara aktif untuk meningkatkan keterserapan pengangguran dan mampu memberikan nilai positif dalam angka statistik aspek ketenagakerjaan. Namun di pihak lain, sektor informal ini mengalami kondisi diskriminatif dan ambivalensi, sehingga sektor ini mengalami kondisi dilema yang seolah-olah menjadi fenomena lumrah yang dialaminya. Peran sektor informal yang sudah terbukti sebagai katup pengaman pada permasalahan pengangguran dan lapangan pekerjaan ini kiranya tidak berhenti pada satu titik yang menggembirakan. Sektor informal tidak serta merta dianggap sebagai dewa penolong dan mendapatkan perhatian pemerintah. Konsentrasi pemerintah adalah tetap berkisar pada ekonomi global, fiskal, penanaman modal asing, pasar uang dan sebagainya. Sektor riil yang telah menunjukkan bukti ketangguhannya tidak atau belum mampu mengalihkan pandangan pemerintah.

Salah satu alasan yang bisa jadi mendasari sikap permerintah ini adalah bahwa dengan perkembangan sektor informal ini penerimaan dari sisi pajak tidak akan berkembang. Karena selama ini pajak terbesar datangnya adalah dari pengusahapengusaha kelas kakapyang memiliki industri raksasa. Kemudian dari sisi pertumbuhan sektor formal, merebaknya sektor informal ini bisa menggangu pertumbuhan ekonomi secara umum. Walaupun menurut Rachbini (1994), sebenarnya keberadaan sektor formal itu tidak dapat dilepaskan. Contoh yang diambil adalah bahwa pada kenyataannya, mereka yang bekerja di sektor formal membeli makanan dari sektor informal.
Hanya ini cara yang dapat mereka lakukan untuk dapat mempertahankan diri di dalam kondisi gaji di sektor formal yang rata-rata rendah.

Sebagai sektor ekonomi yang terpinggirkan, sektor informal sebenarnya telah menorehkan prestasi yang luar biasa pada masa krisis ekonomi. Hal ini diperkuat oleh Priyono (2002) bahwa hasil studi mengenai Peran Sektor Informal Di Masa Krisis menunjukkan bahwa krisis ekonomi sama sekali tidak berimplikasi pada tingginya angka pengangguran; dampak krisis ekonomi di pasar tenaga kerja yang paling nyata adalah turunnya pendapatan riil, khususnya bagi mereka yang berstatus karyawan; dan di masa krisis, tenaga kerja melakukan mekanisme penyesuaian dengan cara mencari pekerjaan sampingan. Hal itu mengklarifikasikan peranan signfikan sektor informal sebagai penyangga (buffer) dalam perekonomian, bahkan di masa krisis.

Pertumbuhan sektor informal dan industri kecil dalam masa krisis ekonomoni ini dipengaruhi oleh beberapa faktor, yaitu 1) sebagian besar usaha kecil memproduksi barang konsumsi dan jasa-jasa dengan elastisitas permintaan terhadap pendapatan yang rendah, maka tingkat pendapatan ratarata masyarakat tidak banyak berpengaruh terhadap permintaan barang yang dihasilkan. Sebaliknya kenaikan tingkat pendapatan juga tidak berpengaruh pada permintaan; 2) sebagian besar usaha kecil tidak mendapat modal dari bank. Implikasinya keterpurukan sektor perbankan dan naiknya suku bunga, tidak banyak mempengaruhi sektor ini. Berbeda usaha skala besar yang banyak tergantung kepada perbankan, jika sektor perbankan bermasalah, maka ikut terganggu kegiatan usahanya, sedangkan usaha kecil dapat bertahan. Di Indonesia, usaha kecil biasanya menggunakan modal sendiri dari tabungan dan aksesnya terhadap perbankan sangat rendah; 3) usaha kecil mempunyai modal yang terbatas dan pasar yang bersaing. Dampaknya usaha kecil mempunyai spesialisasi produksi yang ketat. Hal ini memungkinkan usaha kecil mudah untuk pindah dari usaha yang satu ke usaha lain, hambatan keluar-masuk tidak 
ada; 4) reformasi menghapuskan hambatanhambatan di pasar, proteksi industri hulu dihilangkan, usaha kecil mempunyai pilihan lebih banyak dalam pengadaan bahan baku. Akibatnya biaya produksi turun dan efisiensi meningkat. Akan tetapi, karena bersamaan dengan terjadinya krisis ekonomi, maka pengaruhnya tidak terlalu besar; dan yang terakhir adalah 5) dengan adanya krisis ekonomi yang berkepanjangan menyebabkan sektor formal banyak memberhentikan pekerja-pekerjanya. Para penganggur tersebut memasuki sektor informal, melakukan kegiatan usaha yang umumnya berskala kecil, akibatnya jumlah usaha kecil meningkat.

Pemberdayaan kekuatan kreatif masyarakat ini menjadi kekuatan riil pada masyarakat grassroot. Menurut Wahyuni (2005) sektor informal yang sejak dahulu telah menjadi alternatif pilihan pekerjaan bagi banyak angkatan kerja Indonesia, ketika lokomotif sektor formal tidak mampu mengangkut mereka, semakin diandalkan oleh anggota barisan penganggur, termasuk penganggur baru akibat $\mathrm{PHK}$ sebagai pilihan lapangan kerja satu-satunya yang bisa mereka harapkan.

Tetapi bukti ini tidak cukup untuk membuka kesempatan yang luas bagi perkembangan sektor informal. Secara umum, program-program tersebut cenderung membantu sektor informal dari segi manajemen dan permodalan. Namun hasil yang menggembirakan belum dapat tercapai karena, selain permodalan menjadi masalah utama, pada sektor informal adalah rendahnya tingkat keterampilan dan pendidikan dari para pelakunya. Jika keterampilan merupakan cerminan kasar dari tingkat pendidikan, sebagai gambaran, pada tahun 2005 , sekitar $82 \%$ pekerja di sektor informal berpendidikan SD ke bawah, SLTP $11.6 \%$, SLTA $6.2 \%$ dan diploma/universitas $0.2 \%$. Kondisi demikian menyebabkan rendahnya tingkat produktivitas, sehingga pada dasarnya pertambahan kesempatan kerja baru di sektor informal tidak dapat meningkatkan produktivitas. Argumen serupa juga dikemukakan oleh Widianto (dalam Pitoyo, 2007 : 197), bahwa sektor informal memang fleksibel, luwes, dan mudah dan cepat menyesuaikan diri dengan perubahan keadaan meskipun bersifat lokal. Akan tetapi, disinilah terdapat tumpukan pekerja miskin yang perlu diberdayakan. Menyangkut permasalahan ini, pendekatan pembinaan atau pemberdayaan kurang didukung penataan aturan-aturan untuk melindungi sektor informal.

Selain daripada itu, hal yang paling dilihat adalah kurangnya political will dari pemerintah untuk mengembangkan sektor informal menjadi potensi yang besar dalam mensejahterakan rakyat. Pada persoalan sektor informal perkotaan misalnya, pemerintah lebih suka menggunakan cara-cara primitif seperti pengusiran, penggusuran dan penggunaan kekerasaan sebagai dalih dalam menertibkan para PKL. Kesemrawutan dan kekotoran kota yang ditimbulkan oleh PKL merupakan pemandangan yang umum ditemui di Indonesia, namun bukankah cara-cara yang lebih manusiawi lebih pantas digunakan untuk mengatasi masalah tata kota dan PKL ini, dialog misalnya.

Keberadaan sektor informal yang dilematis ini rasanya hanya akan mengakibatkan perdebatan yang tak berkesudahan dan menjadi masalah klasik yang akan tetap ditemui di masa yang akan datang apabila pemerintah tidak melakukan langkah-langkah nyata dalam melindungi ekonomi rakyat ini. Menurut Rachbini (1994 : 13), kesulitan pemerintah dan birokrasi untuk menggarap dan membangun sektor ekonomi informal secara tuntas sering terbentur oleh beberapa kendala yaitu : 1) kurangnya pengetahuan deskriptif maupun analitis mengenai jenis, unit, dan luas kegiatan ekonomi informal ini; 2) tidak mempunyai kekuasaan birokrasi untuk mencapai daerah pedesaan, pinggiran kota, dan pemukiman kumuh yang kebanyakan digeluti oleh pelaku ekonomi informal ini; 3) kurangnya tenaga yang mampu mengetahui dengan baik seluk beluk ekonomi informal ini; 4) diterapkannya peraturan dan prosedur yang kaku serta tidak luwes dalam sektor informal; dan 5) terdapatnya kenyataan bahwa tidak ada sumber dana yang dapat 
mencukupi permintaan sektor tradisional yang luas ini.

Dalam hal ini, bukan berarti kondisi dilematis yang dialami sektor informal ini terjadi di semua tempat. Pada beberapa tempat, sektor informal ini dikelola dan ditangani dengan baik oleh pemerintah. Namun sayangnya di banyak tempat lain sektor informal ini hanya diakui keberadaannya namun tidak diberdayakan, tidak dikelola atau dengan kata lain hanya didiamkan saja dan menunggu kematiannya. Contoh kasus yang cukup menarik untuk dilihat adalah mengenai kasus penanganan dan kebijakan pemerintah terhadap keberadaan sektor informal perkotaan PKL.

Tidak dapat dipungkiri bahwa permasalahan PKL ini seperti tidak ada habisnya. Diakui sebagai bagian dinamika perekonomian perkotaan tetapi di sisi lain mengundang berbagai macam masalah. Menurut Hetifah (2009), berdasarkan pengamatan terhadap praktik kebijakan perkotaan terhadap PKL selama ini, ada beberapa alasan yang membuat banyak kota-kota gagal mengelola PKL dengan baik. Alasan pertama terkait dengan sikap dan perspektif yang ambivalen, di satu sisi keberadaan PKL dianggap sebagai 'penyelamat' karena telah menyediakan lapangan kerja, memberikan kemudahan bagi warga untuk mendapatkan barang dengan harga murah, menambah daya tarik kota, dan membuat kota menjadi 'hidup'. Kontrasnya, PKL juga diangggap sebagai 'penyakit' yang membuat kota menjadi semrawut dan kotor. Persoalannya, pemerintah daerah umumnya tidak mampu keluar dari situasi ambilvalensi ini sehingga tidak tahu lagi apakah kebijakan yang harus menyesuaikan diri dengan perkembangan PKL ataukah PKL yang harus beradaptasi dengan kebijakan penataan kota yang sudah ada. Alasan kedua menyangkut pemahaman akan persoalan dan akurasi data. Salah satu hambatan yang dihadapi dalam mengatasi masalah PKL di perkotaan adalah tidak tersedianya statistik di tingkat kota yang lengkap, terbarui, dan konsisten. Bahkan banyak kota-kota yang tidak memiliki data paling mendasar seperti berapa jumlah PKL yang ada di wilayahnya pada suatu masa. Jika pemerintah tidak mengetahui berapa jumlah PKL, siapa mereka, dan tidak pula memahami bagaimana sistem kehidupan yang dijalani PKL, akan sulit bagi pemerintah untuk mendefinisikan apa masalah riil yang terkait dengan PKL, dan akibatnya, akan sulit untuk merumuskan solusi yang tepat dan efektif. Ketiadaan data dan informasi ini juga membuat banyak pemerintah daerah cenderung menyepelekan keberadaan PKL serta membuat kebijakan menjadi salah sasaran.

Alasan ketiga menyangkut ketidakjelasan orang atau lembaga apa yang bertanggung jawab mengelola PKL. Sikap ambivalensi tercermin juga dalam kelembagaan pemerintah daerah yang sering memecah tugas pengelolaan PKL setidaknya kepadaduainstitusiyaitu unit 'pemberdayaan' PKL yang biasanya merupakan satu bagian di bawah dinas atau badan pengembangan usaha kecil dan koperasi. Sementara tugas lain adalah tugas 'penertiban' PKL, yang biasanya menjadi tugas pokok dan fungsi (tupoksi) dari lembaga Satuan Polisi Pamong Praja (Satpol PP). Tanpa kepemimpinan yang kuat dari kepala daerah yang bisa menjalankan fungsi koordinasi, situasi ini ini mendorong upaya pengelolaan PKL menjadi sepotong-sepotong, ad hoc, dan tidak konsisten. Alasan keempat adalah kurangnya interaksi antara komunitas PKL dengan pengambil keputusan, baik dari kalangan birokrasi maupun dengan politisi. Di banyak kota, upaya penanganan masalah PKL sering membuat situasi memburuk, bukan sebaliknya. Salah satu sebabnya adalah karena kebijakan tersebut tidak memperoleh legitimasi dan dukungan dari komunitas PKL itu sendiri. Persoalan-persoalan inilah yang masih menjadi fokus utama dan belum mampu diselesaikan oleh pemerintah.

Kegagalan kebijakan pemerintah dalam penanganan PKL ini masih banyak ditemui di banyak kota. Lihat saja Jakarta dengan pertumbuhan penduduk yang luar biasa pesat namun di sisi lain lapangan pekerjaan sangat terbatas. Oleh karena itu pertumbuhan sektor informal perkotaan ini menjadi sangat tinggi. Akibatnya jalur 
pejalan kaki, jembatan penyeberangan bahkan di dalam kereta api kelas ekonomi pun penuh sesak oleh aktivitas perdagangan dari PKL. Lantas yang biasa dilakukan pemerintah propinsi DKI adalah menggusur dan tidak jarang menggunakan caracara kekerasan yang pada akhirnya akan menimbulkan konflik horizontal. Artinya bukan saja kebijakannya yang ditentang, namun satpol PP juga menjadi sasaran kebencian masyarakat. Akibatnya bila ada satpol PP para PKL itu tidak melanggar larangan berjualan namun bila tidak ada satpol PP mereka akan kembali lagi ke tempat-tempat yang dilarang. Paradoks yang dialami Jakarta ini bahkan juga dialami kotakota besar lain di Asia Tenggara sebagai kota yang disebut sebagai kota utama/primate cities (Evers dan Korff, 2002 : 2).

Kondisi yang kurang lebih sama juga terjadi di Bandung. Setia (2009) menyatakan bahwa kebijakan pemerintah Kota Bandung yang di dominasi oleh penggusuran dan relokasi masih kurang berhasil menahan PKL untuk kembali ke jalan.Kondisikondisi semacam ini akan mengakibatkan resistensi dari PKL terhadap kebijakan pemerintah yang pada akhirnya tidak akan menyelesaikan masalah yang sudah ada bahkan tidak tertutup kemungkinan munculnya masalah baru. Bahkan menurut Wardiah (2008) dalam sektor informal ini akan terus tetap ada dan bertahan, sekeras apapun usaha untuk menertibkan, mengusir dan menghapus keberadaan sektor ini di masyarakat.

Kota yang saat ini dianggap sebagai wilayah yang relatif ramah terhadap PKL adalah Solo. Berdasarkan penelitian yang dilakukan Handayani (2006), mendeskripsikan keterlibatan komunitas sektoral dalam proses perencanaan dan penganggaran partisipatif di Kota Solo. Diskusi dalam bentuk FGD dilakukan agar dapat menampung aspirasi masyarakat agar kepentingannya lebih terakomodir oleh kelurahan di wilayah mereka berada. Bappeda juga mendorong komunitas sektoral untuk melakukan FGD yang hasilnya akan digabungkan dengan komunitas lain. Hal ini bisa diindikasikan bahwa anggaran belanja pemkot cukup besar bagi pengembangan kelompok marjinal. Disini juga menekankan pentingnya proses pelibatan masyarakat marjinal dalam perencanaan dan penganggaran partisipatif bagi pengembangan kapasitas masyarakat.

Selanjutnya Hetifah (2009) juga melihat bahwa hasil yang dicapai oleh kota Solo sebagai kota yang ramah terhadap PKL ini bukanlah hasil yang didapat secara instan dan tanpa kerja keras. Penanganan PKL Banjarsari adalah contoh yang cukup representatif dimana partisipasi dan dialog dengan masyarakat menjadi hal yang sangat krusial. Banjarsari adalah salah satu kawasan di Kota Solo dimana masalah PKL pernah menjadi problem akut. Pasar Klithikan Banjarsari mulai muncul sekitar tahun 1997, ketika krisis ekonomi mulai melanda Indonesia. Jumlah PKL pun berkembang cukup pesat, yang mencapai 1000 PKL pada tahun 2001.Pertemuan antara kepentingan pemerintah dan PKL dimulai sejak tahun 2002. Selama kurun waktu antara 2002-2006 telah terjadi berbagai dialog, ketegangan dan perbedaan pendapat menyangkut respon pemerintah yang akan merelokasi PKL ke wilayah Semanggi. Dalam dialog tersebut, usulan masyarakat diakomodir sementara pemerintah juga mempersiapkan sarana dan prasarana yang dibutuhkan dalam relokasi dan keberlanjutan kehidupan PKL di tempat baru tersebut. Mungkin ini bisa menjadi inspirasi bagi daerah-daerah lain di Indonesia.

Diantara sekian banyak reaksi represif dari pemerintah daerah, Solo memiliki pendekatan yang lain yaitu pendekatan komunikasi dan interaksi. Menurut Utomo (2005), untuk mengatasi persoalan-persoalan yang muncul dari PKL, Pemerintah Kota Surakarta telah mengambil suatu sikap tertentu, dengan cara membuat strategi program pembinaan, penataan, dan penertiban. Strategi tersebut dituangkan dalam bentuk program kerja tahunan yang memuat aktivitas-aktivitas pembinaan, penataan, dan penertiban. Dalam bidang pembinaan, kegiatan yang ditempuh oleh Pemerintah Kota adalah melakukan usaha-usaha pembinaan dengan 
cara menumbuhkan pengertian para PKL akan hak-haknya, dan juga memberikan suatu pemahaman mengenai kewajibankewajiban yang harus mereka lakukan. Program pembinaan ini dilakukan dengan cara melaksanakan sosialisasi kebijakan lewat penyuluhan atau pertemuan-pertemuan dengan paguyuban-paguyuban PKL. Dalam bidang penataan, dilakukan penataan letak dan bentuk dasaran PKL yang sesuai dengan Perda dan SK Walikota, penekanan tempat usaha pada bentuk knock down ( bongkar pasang), serta melakukan relokasi dalam rangka penertiban. Aktivitas penertiban dilakukan dengan cara merelokasi para PKL yang menempati jalur-jalur hijau, badanbadan jalan, taman-taman kota, dan tempattempat larangan lainnya. Dengan demikian PKL tetap menjadi alternatif usaha yang didekati dengan prinsip kemanusian oleh kekuasaan.

Menurut Sutrisno (2007), sinergi yang baik antara pemerintah, masyarakat dan PKL dapat terjalin, khususnya pada kasus kota Solo. Penataan Pedagang Kaki Lima bertujuanuntukmemberdayakanusahasektor informal PKL dengan jaminan perlindungan, pembinaan dan pengaturan usaha agar lebih berdayaguna dan berhasilguna, serta dapat meningkatkan kesejahteraan PKL khususnya dan masyarakat kota umumnya. Pemkot beserta seluruh elemen masyarakat mendukung usaha PKL dengan menciptakan kondisi yang kondusif. Untuk mengatasi permasalahan, penempatan lokasi usaha PKL dapat dilakukan dengan mempertimbangkan keterikatan usaha PKL dengan lingkungan dan konsumen, latar belakang kebutuhan konsumen (direncanakan terlebih dahulu atau tidak), dan keindahan lingkungan, keamanan, serta ketertiban, yang dapat dilakukan dengan beberapa cara sebagai berikut : relokasi ke suatu tempat; pembentukan zoning (pembentukan kawasan PKL) untuk menampung PKL yang diperlukan masyarakat sekitar, tetapi berdagang di daerah larangan; pembentukan zoning dengan membangun kios dan bekerjasama dengan instansi yang memiliki lahan luas dan komunitasnya sangat membutuhkan pelayanan dari PKL; pembuatan shelter sebagai fasilitas umum untuk warga dan tempat usaha PKL; penggunaan tenda knock down (bongkar pasang) dan gerobak dorong untuk tempat dan sarana dagang PKL yang menempati daerah-daerah keramaian dengan memperhatikan keindahan dan keamanan lingkungan. Selain daripada itu, diperlukan penyuluhan dan pembinaan manajerial oleh Pemkot dan elemen masyarakat lain agar usaha PKL dapat mandiri dan berkembang. Pembinaan dan penataan nonfisik bertujuan mengubah mental dan perilaku PKL yang menganut prinsp "pokoknya" menjadi warga yang sadar hukum dan berwawasan lingkungan. Di lain pihak, penertiban dan penegakan Perda secara rutin yang bertujuan agar perundangundangan dan peraturan dipatuhi bersama.

Dari kasus PKL di Surakarta ini, Rahayu (2007) juga mengemukakan bahwa keberadaan PKL sebagai bagian terbesar dari sektor informal adalah sebuah realita. Idealisme kita adalah mewadahi dan melokalisir serta mengendalikan pertumbuhannya dengan peraturan, pemberdayaan dan hak hidup bagi yang lain sehingga tercipta ruang publik yang ekonomis, dapat diakses oleh seluruh lapisan masyarakat. Karena keberadaan sektor informal, angka pengangguran dan derita kemiskinan tidak sedasyat yang ditakutkan banyak pihak. Meski diakui jasa besarnya dalam menyerap surplus angkatan kerja, PKL masih tetap dianaktirikan, dipinggirkan bahkan sering dianggap sebagai penyakit dalam perekonomian. Pendekatan yang bijaksana dapat mengangkat harkat dan martabat PKL agar mereka bukan lagi dianggap sebagai penyakit yang harus dibasmi namun justru menjadi penyeimbang bagi pemenuhan kebutuhan masyarakat.

Berkaca dari situasi Solo ini, maka sebenarnyahubunganyangbaikdanharmonis antara sektor informal dengan pemerintah bukan mustahil terjalin. Ada banyak pendekatan, komunikasi yang intens serta konsesnsus bersama yang harus dipahami dan dipatuhi untuk menjaga konsistensi kesepakatan yang dibuat tersebut. Dan bukan tidak mungkin, pemerintah di daerah yang 
lain juga memiliki pandangan yang sama akan hal ini walaupun pendekatannya akan disesuaikan dengan situasi dan kondisi yang ada pada masing-masing tempat. namun sekali lagi, bahwa untuk menciptakan situasi ini membutuhkan kerja keras dan komitmen bersama antar seluruh elemen masyarakat.

\section{SIMPULAN}

Bahwa sektor informal sebagai salah satu katup pengaman ekonomi dan penyerap tenaga kerja terbesar adalah tidak diragukan. Namun di sisi lain keberadaannya yang sering diabaikan adalah kenyataan yang tidak bisa diingkari lagi. Dilematisnya posisi sektor informal ini nampaknya terus berkelanjutan apabila tidak ada langkah nyata yang dilakukan oleh pemerintah untuk mengentaskannya. Persoalan tenaga kerja yang memiliki kualifikasi pendidikan yang minim dan ketrampilan yang terbatas juga harus dipikirkan lagi. Perluasan akses, kesempatan, permodalan dan kebijakan yang ramah terhadap sektor informal harus lebih diperhatikan lagi. Hal ini tidak lain adalah untuk meredam efek negatif dari keberadaan sektor informal dan memberdayakan efek positifnya agar mampu meningkatkan kesejahteraan masyarakat. Hubungan dialogis antara pemerintah sebagai pengambil kebijakan dan mereka yang berkecimpung dalam sektor informal sebaiknya lebih diintensifkan. Karena, walaupun belum banyak yang mengaplikasikan tindakan ini, contoh hubungan yang harmonis di Solo cukup menjadi cermin yang representatif. Mengingat bahwa sektor informal ini memiliki tingkat keterjangkauan untuk masyarakat dari segala lapisan.

\section{DAFTAR PUSTAKA}

Effendi, T.N. dan Manning, C. 1995. Sumber Daya Manusia, Peluang Kerja dan Kemiskinan. Yogyakarta : Tiara Wacana.

Evers, H.D. \& Korff, R. 2002. Urbanisme di Asia
Tenggara, Makna dan Kekuasaan Dalam RuangRuang Sosial. Jakarta : Yayasan Obor Indonesia. Gilbert, G. \& Gugler, J. 1996. Urbanisasi dan Kemiskinan Di Dunia Ketiga. Yogyakarta : Tiara Wacana.

Handayani, S. 2006. Pelibatan Masyarakat Marginal dalam Perencanaan dan Penganggaran Partisipatif: Sebuah Pengalaman di Kota Solo. Solo : KOMPIP dan The Ford Foundation.

Hetifah, \& Sumarto. 2009. Kebijakan Ramah PKL Di Perkotaan: Belajar Dari Kota Solo. Jurnal Analisis Sosial. 14 (1): 15-25.

Manning, C. dan Effendi, T.N. 1995. Urbanisasi, Pengangguran dan Sektor Informal di Kota. Jakarta : Gramedia.

Mardiah, A.W. 2008. Dinamika Sektor Informal (Suatu Kajian Tentang Eksistensi Pedagang Kaki Lima). Jurnal Media Akademik. 2 (1): 5560.

Murid, Y. 2010. Ekonomi laki, ekonomi perempuan. Jurnal Komunitas. 2 (2): 59-67.

Pitoyo, A.J. 2007. Pengangguran dan Kebijakan Penanganan dalam Sumber Daya Manusia, Tantangan Masa Depan (ed.Tukiran). Yogyakarta : Pustaka Pelajar dan PSKK UGM.

Priyono, E. 2002. Mengapa Angka Pengangguran Rendah Di Masa Krisis? : Menguak Peranan Sektor Informal Sebagai Buffer Perekonomian. Jurnal Ekonomi Dan Kewirausahaan. 1 (2): 30-40.

Rachbini, D. J. \& Hamid, A. 1995. Sektor Informal Perkotaan. Jakarta: LP3ES.

Rahayu, M.J. 2007. Keseimbangan Pelaku Ekonomi Di Ruang Publik Kasus Kawasan Tipes Surakarta. Arsitektura. 5 (1): 15-20.

Setia, R. 2009. Dunia Yang Dinamis: Studi Kasus Para Pekerja Informal Di Kota Bandung. Jurnal Analisis Sosial. 14 (1): 25-35.

Siswoyo, B.B. 2009. Pengembangan Jiwa Kewirausahaan Di Kalangan Dosen Dan Mahasiswa. Jurnal Ekonomi Bisnis .14 (2): 35-45.

Sutrisno, B, dkk. 2007. Pola Penataan Pedagang Kaki Lima (PKL) Di Kota Surakarta Berdasar Paduan Kepentingan PKL, Warga Masyarakat, Dan Pemerintah Kota. Jurnal Penelitian Humaniora. 8 (2): 166-175.

Utomo, I.H. 2005. Implementasi Kebijakan Penataan Dan Pembinaan Pedagang Kaki Lima (Studi Kasus Implementasi Kebijakan Penataan Dan Pembinaan Pedagang Kaki Lima Kota Surakarta Ditinjau Dari Perspektif Komunikasi Pemerintah Kota Dan PKL ). Spirit Publik. 1 (1): $13-22$.

Wahyuni, D. 2005. Peran Sektor Informal Dalam Menanggulangi Masalah Pengangguran Di Indonesia. Jurnal Economia. 1 (1): 54-64.

Zed, M. 2008. Metode Penelitian Kepustakaan. Jakarta : Yayasan Obor Indonesia. 